University of Michigan Law School

University of Michigan Law School Scholarship Repository

\title{
Legislative Intent and Legislative History in Michigan
}

\section{Kincaid C. Brown}

University of Michigan Law School, kcb@umich.edu

Available at: https://repository.law.umich.edu/librarian/9

Follow this and additional works at: https://repository.law.umich.edu/librarian

Part of the Courts Commons, Legal Writing and Research Commons, Legislation Commons, and the State and Local Government Law Commons

\section{Recommended Citation}

Brown, Kincaid C. "Legislative Intent and Legislative History in Michigan," Legal Reference Services Q., 30, no. 1-2 (2011): 51-61.

This Article is brought to you for free and open access by the Other Publication Series at University of Michigan Law School Scholarship Repository. It has been accepted for inclusion in Law Librarian Scholarship by an authorized administrator of University of Michigan Law School Scholarship Repository. For more information, please contact mlaw.repository@umich.edu. 
Legislative Intent and Legislative History in Michigan

Kincaid C. Brown

Head of Electronic \& Systems Services

University of Michigan Law Library

801 Monroe St.

Ann Arbor, MI 48109-1210

\section{Abstract}

Determining legislative intent is one of the key roles that the judicial system plays in Michigan, and legislative history can be a useful tool for evaluating the intent of the legislature when enacting a law. However, legislative history resources can be difficult to gather and some resources may not be persuasive in Michigan courts. This article provides a brief description of the Michigan legislative process, the court's view of using legislative history to determine legislative intent, and a list of Michigan legislative history resources.

\section{Keywords}

Michigan, legislative intent, legislative history, legislation, bill, legal research, courts

Introduction

Determining legislative intent is one of the key roles that the judicial system plays in Michigan. Legislative history can be a useful tool for evaluating legislative intent but legislative history research can be complex and confusing. Additionally, legislative history is often of limited value in determining legislative intent in Michigan. The purpose of this article is to provide an overview of how to find and use legislative history when determining legislative intent in Michigan. Included is a brief description of the legislative process in Michigan, a more 
detailed discussion of how Michigan courts use legislative history in the determination of legislative intent, and a brief review of Michigan legislative history resources.

\section{The State Legislative Process in Brief}

The Michigan Legislature has two houses, the House of Representatives ("House") and the Senate, and a bill may be introduced in either house. ${ }^{1}$ Each session of the Legislature is two years and each bill introduced in the biennial legislative session is assigned a consecutive bill number. Upon introduction, a bill is read and then referred to a standing committee ${ }^{2}$ where it is debated, and a hearing on the bill may be held. ${ }^{3}$

The committee will then decide to take one of a number of actions, including to report ${ }^{4}$ the bill with or without a favorable recommendation, ${ }^{5}$ to take no action on the bill, ${ }^{6}$ to send the bill to another committee, ${ }^{7}$ or to not report the bill out of committee. ${ }^{8}$ Bills that are reported

\footnotetext{
${ }^{1}$ Mich. Const. art. IV §22.

2 Michigan Senate, Senate Rules (2011), (2009-2010).

${ }^{3}$ Senate Rule 2.107(a), House Rule 34(7)

${ }^{4}$ Senate Rule 2.203(a), House Rule 45

${ }^{5}$ House Rule 34(3)(c)

${ }^{6}$ House Rule $34(3)(d)$

${ }^{7}$ Senate Rule 2.203(c)

${ }^{8}$ Senate Rule 2.204
}

http://www.legislature.mi.gov/documents/Publications/rules/senate_rules.pdf (last visited Jan. 18, 2011) [hereinafter Senate Rule] (Rule 3.203(a)). Also published in Michigan Legislature, Michigan Legislative Handbook \& Directory 70 (2009-2010) Michigan House of Representatives, Standing Rules of the House of Representatives in Accordance to the Michigan Constitution Article IV, Section 16 (2011), http://www.legislature.mi.gov/documents/Publications/rules/house_rules.pdf (last visited Jan. 18, 2011) [hereinafter House Rule] (Rule 41(4)). Also published in Michigan Legislature, Michigan Legislative Handbook 156 
favorably out of the standing committee are read and considered by the House and amendments may be recommended and adopted. A bill may then be advanced for a "Third Reading." Under the Michigan Constitution, each bill must be read three times before passage. ${ }^{9}$ After the Third Reading the bill may be passed or defeated by a majority roll call vote and the names and votes of the legislators are published in that chamber's Journal, ${ }^{10}$ although some measures require a super-majority. ${ }^{11}$ At this point, action on a bill may also be postponed. Note further that a bill must not "embrace more than one object," the title shall express the subject of the law, ${ }^{12}$ and it may not be passed until it is in the possession of each house for five days. $^{13}$

If a bill is passed by one house it is sent to the other for consideration using the same process as a bill originally introduced into that house. If the bill is passed in the same form by both houses it is enrolled, printed, and sent to the Governor. If the bill is passed by the two houses with differences, it is returned to the house in which it originated where that house can accept the other house's version. If the original house accepts the substitute bill from the second house, the bill is enrolled, printed, and sent to the Governor. If the original house rejects the substitute bill version, the two houses review the bill in conference committee and

\footnotetext{
${ }^{9}$ Mich. Const. art. IV §26.

${ }^{10}$ Id. See discussion infra Section III for House \& Senate Journals.

${ }^{11}$ See, e.g., Mich. Const. art. IV $\$ 15$ (long term borrowing of money by the State), Mich. Const. art. IV §29 (local or special acts), Mich. Const. art. IV $\S 30$ (appropriation for local or private purposes).

${ }^{12}$ Mich. Const. art. IV §24.

${ }^{13}$ Mich. Const. art. IV $§ 26$.
} 
the conferees attempt to reach a compromise regarding the bill's differences. ${ }^{14}$ Note that the Constitution mandates that no bill shall be "altered or amended on its passage through either house so as to change its original purpose.."15 If the conferees report is approved by both houses, the bill is enrolled, printed, and sent to the Governor.

The Governor has fourteen days to sign or veto the bill. ${ }^{16}$ After fourteen days the bill becomes law if the legislature is in session or recess, but if the legislature is adjourned within the fourteen day period and the Governor has not signed the bill it does not become law. ${ }^{17}$ The legislature may override the Governor's veto with a two-thirds majority vote in each house. ${ }^{18}$ Acts do not take effect until 90 days after the legislative session ends unless two-thirds of each house votes to give the act immediate effect. ${ }^{19}$

II. Legislative Intent and Legislative History in Michigan

According to Black's Law Dictionary, legislative intent is "the design or plan that the legislature had at the time of enacting a statute..$^{20}$ In Michigan, the primary aim of the courts

\footnotetext{
${ }^{14}$ See Michigan House of Representatives and Senate, Joint Rules of the House of Representatives and Senate (Rule 8) (2009), http://www.legislature.mi.gov/documents/Publications/rules/joint_rules.pdf (last visited Jan. 18, 2011). Also published in Michigan Legislature, Michigan Legislative Handbook 87 (2009-2010).

${ }^{15}$ Mich. Const. art. IV §24.

${ }^{16}$ Mich. Const. art. IV §33.

${ }^{17} / d$.

${ }^{18} / d$.

${ }^{19}$ Mich. Const. art. IV §27.

${ }^{20}$ Black's Law Dictionary 919 (8th ed. 2004).
} 
when interpreting statutes is to "give effect to legislative intent.." ${ }^{21}$ The words of the statute are the best evidence of legislative intent ${ }^{22}$ and the "starting point in every case involving construction of a statute. ${ }^{23}$ Judicial construction of a statute is justified when a statute is ambiguous and "reasonable minds can differ" regarding the meaning of the statute ${ }^{24}$ or when the language employed by the legislature is "susceptible to more than one interpretation." 25

When the language of the statute is clear and unambiguous, judicial construction is not permitted ${ }^{26}$ and nothing may be read into the statute that was not within the intent of the legislature as apparent in the language of the statute, ${ }^{27}$ nor may courts speculate regarding intent beyond the language of the statute. ${ }^{28}$ Even when a statute may appear to be unwise or unfair, there is no basis for judicial construction and the "law must be enforced as written." ${ }^{29}$ It is presumed that the legislature is familiar with the principles of statutory construction. ${ }^{30}$

\footnotetext{
${ }^{21}$ In re MCI Telecomm. Complaint, 596 N.W.2d 164, 174 (Mich. 1999); Frankenmuth Mut. Ins. Co. v. Marlette Homes, Inc., 573 N.W.2d 611, 613 (Mich. 1998); Twentieth Century Fox Home Entm't, Inc. v. Dep't of Treasure, 716 N.W.2d 598, 601 (Mich. Ct. App. 2006) (citing Neal v. Wilkes, 685 N.W.2d 648, 650 (2004)).

${ }^{22}$ Shinholster v. Annapolis Hosp., 685 N.W.2d 275, 279 (Mich. 2004).

${ }^{23}$ House Speaker v. State Admin. Bd., 495 N.W.2d 539, 549 (Mich. 1993) (citing Int'l Bhd. of Teamsters v. Daniel, 439 U.S. 551, 558 (1979)).

${ }^{24}$ In re MCl Telecomm. Complaint, 596 N.W.2d at 174; Adrian Sch. Dist. v. Mich. Pub. Sch. Employees' Retirement Sys., 582 N.W.2d 767, 769 (Mich. 1998).

${ }^{25}$ Rowell v. Security Steel Processing Co., 518 N.W.2d 409, 412 (Mich. 1994).

${ }^{26}$ Id. at 411; Lorencz v. Ford Motor Co., 483 N.W.2d 844, 847 (Mich. 1992).

${ }^{27}$ In re S.R., 581 N.W.2d 291, 293 (Mich. Ct. App. 1998).

${ }^{28}$ Pohutski v. City of Allen Park, 641 N.W.2d 219, 226 (Mich. 2002).

${ }^{29}$ Fowler v. Doan, 683 N.W.2d 682, 687 (Mich. Ct. App 2004) (citing Smith v. Cliffs on the Bay Condo. Ass'n, 617 N.W.2d 536, 541 (Mich. 2000).

${ }^{30}$ People v. Hall, 215 N.W.2d 166, 174 (Mich. 1976).
} 
When judicial interpretation is necessary the court must read the statute in light of the harm it is meant to remedy ${ }^{31}$ and give the statutory language a reasonable construction that best accomplishes the purposes of the statute. ${ }^{32}$ In addition, the court should presume the meaning of the plain ${ }^{33}$ or common sense ${ }^{34}$ language of the state and that the legislature intended the meaning of the language it chose ${ }^{35}$ unless a literal construction would produce absurd results clearly inconsistent with the reasoning of the statute. ${ }^{36}$ Every word of a statute should be given meaning and the court should avoid a construction that would "render any part of the statute surplusage or nugatory." ${ }^{37}$ The legislature is presumed to understand the "primary, ordinary, and generally understood" meaning of the words chosen, ${ }^{38}$ and the court may consult dictionary definitions ${ }^{39}$ of terms not defined in the statute itself. ${ }^{40}$

When the language of a statute is ambiguous, courts may look at the legislative history of an act and the history of the time it was enacted ${ }^{41}$ to determine the meaning of the statute

\footnotetext{
${ }^{31}$ Marquis v. Hartford Accident \& Indem., 513 N.W.2d 799, 802 (Mich. 1994).

${ }^{32}$ Frankenmuth Mut. Ins. Co. v. Marlette Homes, Inc., 555 N.W.2d 510, 513 (Mich. Ct. App. 1996)

${ }^{33}$ Elezovic v. Ford Motor Co., 697 N.W.2d 851, 857 (Mich. 2005).

${ }^{34}$ In re Certified Questions, 331 N.W.2d 456, 461 (Mich. 1982).

${ }^{35}$ Owendale-Gagetown Sch. Dist. v. State Bd. of Educ., 317 N.W.2d 529, 531 (Mich. 1982).

${ }^{36}$ Frankenmuth Mut. Ins. Co., 555 N.W.2d at 513.

${ }^{37}$ In re MCl Telecomm. Complaint, 596 N.W.2d 164, 175-76 (Mich. 1999) (citing Altman v. Meridian Twp., 487 N.W.2d 155, 160 (Mich. 1992)).

${ }^{38}$ General Elec. Credit Corp. v. Wolverine Ins. Co., 362 N.W.2d 595, 601 (Mich. 1984).

${ }^{39}$ Griffith ex rel. Griffith v. State Farm Mut. Auto. Ins. Co., 697 N.W.2d 895, 899 (Mich 2005).

${ }^{40}$ Cain v. Waste Mgmt., Inc., 697 N.W.2d 130, 134 (Mich. 2005) (citing W.S. Butterfield Theatres, Inc. v. Dep't of Revenue, 91 N.W.2d 269, 271 (Mich. 1958)) (holding that court must use definition supplied by statute).

${ }^{41}$ Great Lakes Steel Div., Nat'I Steel Corp v. Dep't of Labor, 477 N.W.2d 124, 126 (Mich. Ct. App. 1991)
} 
and the statute's purpose. ${ }^{42}$ Resorting to legislative history is acceptable only "where a genuine ambiguity exists in the statute" and that it "cannot be used to create an ambiguity where one does not otherwise exist." ${ }^{43}$

Not all legislative history is of equal value. ${ }^{44}$ Legislative history is most valuable when there is evidence therein of an intent to overrule a previous judicial construction (because "a court may be able to draw reasonable inferences about the Legislature's intent" ${ }^{45}$ or a consideration of alternatives in statutory language ${ }^{46}$ (because "by comparing alternative legislative drafts, a court may be able to discern the intended meaning for the language actually enacted") ${ }^{47}$ Accordingly, the Michigan courts have held that the House \& Senate Journals ${ }^{48}$ and bill texts ${ }^{49}$ are the most important sources of legislative history as these sources are those that detail the legislature's actions, reasoning, amendments, and language revisions for a given bill. Bill analyses ${ }^{50}$ and committee reports, ${ }^{51}$ on the other hand, have limited value or are a "feeble indicator of legislative intent." ${ }^{52}$ Bill analyses especially are generally unpersuasive $e^{53}$

\footnotetext{
${ }^{42}$ People v. Hall, 215 N.W.2d 166, 175 (Mich. 1976); In re Brzezinski, 542 N.W.2d 871, 877 (Mich. Ct. App. 1995) (citing Great Lakes Steel Div., 477 N.W.2d at 126).

${ }^{43}$ In re Certified Question, 659 N.W.2d 597, 600 n. 5 (Mich. 2003).

${ }^{44} / d$.

${ }^{45} / d$.

${ }^{46} / d$.

${ }^{47}$ Id.

${ }^{48}$ See discussion infra Section III for House \& Senate Journals.

${ }^{49}$ Brzezinski v. Brzezinski, 542 N.W.2d 871, 877 (Mich. Ct. App. 1995).

${ }^{50}$ In re Certified Question, 659 N.W.2d 597, 600 n. 5 (Mich. 2003); Frank W. Lynch \& Co. v. Flex Techs., Inc. 624 N.W.2d 180, 184 (Mich. 2001).
} 
and should be "entitled to little judicial consideration" ${ }^{54}$ because they are prepared by House and Senate staff members and may not represent the views of any legislator, ${ }^{55}$ are not part of the official legislative record in Michigan, ${ }^{56}$ and are created outside of the legislative process. ${ }^{57}$ However, bill analyses may sometimes be of probative value. ${ }^{58}$

III. Sources of Legislative History

Journal of the House of Representatives of the State of Michigan. Lansing: State of Michigan. Journal of the Senate of the State of Michigan. Lansing: State of Michigan. (Hereinafter House

\section{\& Senate Journals)}

The House \& Senate Journals are the official record of Michigan legislative action, covering the daily activities in the two houses of the Michigan Legislature. However, unlike their federal counterpart, the Congressional Record, these publications do not contain a verbatim transcript of the daily happenings of the houses. They do contain information on citation, roll call votes, amendments to bills, legislator attendance, committees that considered the

\footnotetext{
${ }^{51}$ People v. Schut, 695 N.W.2d 551, 554 (Mich. Ct. App. 2005).

${ }^{52}$ Frank W. Lynch \& Co., 624 N.W.2d at 184.

${ }^{53} / d$.

${ }^{54}$ In re Certified Question, 659 N.W.2d at 600 n.5.

${ }^{55}$ Frank W. Lynch \& Co., 624 N.W.2d at 185 n.7.

${ }^{56}$ In re Certified Question, 659 N.W.2d at 600 n.5.

${ }^{57} / d$.

${ }^{58}$ See, e.g., Seaton v. Wayne Co. Prosecutor, 590 N.W.2d 598, 602 n.3 (Mich. Ct. App. 1998) (citing North Ottawa Cmty. Hosp. v. Kieft, 578 N.W.2d 267, 272 n.12 (Mich. 1998)); Nemeth v. Abonmarche Dev., Inc., 576 N.W.2d 641, 647 n.4 (Mich. 1998).
} 
legislation, and bill sponsors. In addition, the Bill Histories sections contain a list of actions taken on each bill, the date of the actions, roll call vote results, and for bills that were passed, a notation of what Act and Code sections are being amended.

Availability:

- Print

o House Journal, 1836- (covers 1835 to present).

o Senate Journal, 1836-.

- Online

o Michigan Legislature website, ${ }^{59}$ House \& Senate Journals, 1995 to present. Direct links to relevant pages also linked from each bill's information page. $^{60}$

o LLMC Digital, House Journal, 1835 to 1997 scattered holdings, completion of collection is in process; Senate Journal, 1835 to 1997 scattered holdings, completion of collection is in process.

o Westlaw (as of this writing): MI-LH (House \& Senate Journals 1997/1998 to $2007 / 2008$, bill analyses $1997 / 1998$ to $2006 / 2007$ ), MI-LH-JRNLS (1997/1998 to $2007 / 2008)$,

- Microfiche

\footnotetext{
${ }^{59}$ Michigan Legislature, Journals, http://www.legislature.mi.gov/mileg.aspx?page=journals (last visited Nov. 13, 2008).

${ }^{60}$ Michigan Legislature, Bills, http://www.legislature.mi.gov/mileg.aspx?page=Bills (last visited Nov. 13, 2008).
} 
o LLMC, Michigan House Journals, 1835 to 1997; Michigan Senate Journals, 1835 to 1997.

\section{Bill Analyses. Various agencies. Lansing: State of Michigan.}

Bill analyses analyze pending legislation and include a summary of issues the bill addresses, arguments for and against the bill, and other legislative information. Bill analyses are written by state agencies, the House Legislative Analysis Section, the Legislative Analysis Section of the Senate Fiscal Agency, and legislative staff members, but the most widely available analyses are those of the House Fiscal Agency and Senate Fiscal Agency. Not every bill receives an analysis and detailed analyses are limited to bills that have been amended, passed either legislative house, are reported by committee, or are enrolled. A single bill may have a number of analyses as a single agency may update its analysis as the bill is amended. ${ }^{61}$ Availability:

- Print

o Generally 1968-; the Senate Fiscal Agency ceased distributing analyses in print in 2005. The Library of Michigan has scattered holdings dating from 1960.

- Online

o The Michigan Legislature website links the analyses from each bill's information page ${ }^{62}, 1997$ to present.

\footnotetext{
${ }^{61}$ Susan Adamczak, Researching Online Sources for Michigan Legislative History, 85 Mich. B. J. 46 (2006).

${ }^{62}$ Michigan Legislature, supra note 2.
} 
o Westlaw (as of this writing): MI-LH (House \& Senate Journals 1997/1998

to $2007 / 2008$, bill analyses $1997 / 1998$ to $2006 / 2007$ ), MI-LH-REP

(1997/1998 to 2006/2007),

House Bill. Lansing: State of Michigan Legislature (as introduced). Senate Bill. Lansing: State of Michigan Legislature (as introduced). Enrolled House Bill. Lansing: State of Michigan Legislature (as passed by both houses). Enrolled Senate Bill. Lansing: State of Michigan Legislature (as passed by both houses).

A bill may have a number of versions between the time it is introduced in the Michigan Legislature and the time it is passed by both houses and sent to the Governor for signature. The two most widely available bill versions are the bill as introduced and the bill as it was enrolled. Other intermediate versions of bills may also be available and may reflect changes made to the bill by the Senate and House. When compiling a legislative history a comparison of different versions of a bill may be helpful in tracking amendments and changes in language between the bill as introduced and the final bill.

Availability:

- Print

o 1835-.

- Online 
o Michigan Legislature website ${ }^{63}, 1997$ to present; introduced, passed by the original chamber of the legislature, passed by the second legislative chamber, and enrolled.

o Lexis: MICH;MIBILL (Current session legislative activity and full-text bills), MICH;MITEXT (full-text of bills pending in current legislative session), MICH;MITRCK (bill tracking for current legislative session), MICH;MILH (bill history, 1999 to present).

o Westlaw: MI-BILLS (summaries and full-text bills for current session), MIBILLTXT (full-text bills for current session), MI-BILLTRK (bill tracking for current session), MI-BILLTXT-OLD (full-text bills from 1991), MI-BILLTRKOLD (bill tracking from 1991).

- Microfilm

o Original House and Senate Bills. Lansing: Michigan Dept. of State, Office of the Great Seal. This set covers 1844-2002.

Public and Local Acts of the Legislature of the State of Michigan. Lansing: State of Michigan.

The Public and Local Acts of the Legislature of the State of Michigan and its predecessor title, Acts of the Legislature, is the annual official compilation of legislation enacted by the Michigan Legislature. The session laws are included in the bound volumes in the chronological order of passage.

Availability:

\footnotetext{
${ }^{63}$ Michigan Legislature, supra note 2.
} 
- Print

o $1835 / 1836$ session to present.

- Online

o Michigan Legislature website ${ }^{64}$

o HeinOnline, 1995 to 2005; Hein plans on adding to this run.

o Lexis: MICH;MIALS (Advance Legislative Service).

o Westlaw: MI-LEGIS (acts passed in current legislative session), MI-LEGISOLD (acts passed in previous legislative session, 1988 to one year ago)

- Microfiche

o Hein, 1835 to 2005, part of the Session Laws of American States and Territories microfiche series. Hein also has Michigan Territory session laws, $1805-1835$.

o LLMC, 1835 to 1997. LLMC also has Michigan Territory session laws, 1821-1835.

Michigan Compiled Laws Annotated. St. Paul: West Pub. Co. Michigan Compiled Laws Service. Charlottesville, VA: LexisNexis.

Michigan Compiled Laws Annotated (M.C.L.A.) and Michigan Compiled Laws Service (M.C.L.S.) are two useful sources for starting Michigan legislative history research. These publications include a history for each section of the codified Michigan laws. This history will

\footnotetext{
${ }^{64}$ Michigan Legislature, Public Acts, http://www.legislature.mi.gov/mileg.aspx?page=publicacts (last visited Nov. 13, 2008).
} 
identify for the researcher the year and number of the Public Law that became the basis for the section and the year and number of each Public Law that later amended that section. In addition, M.C.L.A. includes an extensive Statutory Note section that details the amendments to each code section. Once a researcher has the Public Law citation, he or she will be able to locate the original bill number and the legislative history that exists for that bill. Both M.C.L.A. and M.C.L.S. also include an advance legislative service that includes newly passed session laws with deletions and additions noted, and tables that show which code sections are affected. The official state publication, Michigan Compiled Laws, has not been updated in print since its publication in 1979, although the version on the Michigan Legislature website is current.

Availability

- Print

o M.C.L.A, 1967 to present.

o M.C.L.S., 2001 to present.

- Online

o Michigan Legislature website ${ }^{65}$ (current version of each Michigan Compiled Laws code section).

o Lexis: MICH;MICODE (M.C.L.S., Constitution, Court Rules, Advance Legislative Service combined), MICH;CODE (M.C.L.S.), MICH;MIARCH (M.C.L.S., archive from 1991)

\footnotetext{
${ }^{65}$ Michigan Legislature, Michigan Compiled Laws: Basic Search, http://www.legislature.mi.gov/mileg.aspx?page=MCLBasicSearch (last visited Nov. 19, 2008).
} 
o Westlaw: MI-ST-ANN (M.C.L.A., Constitution, Court Rules, Advance Legislative Service), MI-ST (M.C.L.A., Constitution, Court Rules, Advance Legislative Service in unannotated form), MI-ST-ANNYY (historical M.C.L.A. by year, 1989 to one year ago).

- Microfiche

o Michigan Superseded State Statutes Collection. Buffalo: William S. Hein \& Co., 1846 to 1967.

Michigan Law Revision Commission Report Annual Report. St. Paul: West Pub. Co.

The Michigan Law Revision Commission examines Michigan common law and statutes and recommends reforms to the legislature. The Annual Report lists public laws that were enacted based on the Commission's recommendations.

Availability:

- Print

o 1966 to present.

- Online

o Michigan Law Revision Commission website, ${ }^{66} 1995$ to present.

\section{Additional Legislative History Sources}

\footnotetext{
${ }^{66}$ Michigan Law Revision Commission, Annual Reports of the MLRC, http://council.legislature.mi.gov/mlrc.html (last visited Nov. 19, 2008).
} 
Other sources ${ }^{67}$ of Michigan legislative history information are of a more irregular or archival nature. One such source is reports promulgated by executive agencies, commissions, or task forces. These reports study a particular issue and are accordingly located by subject and not in relation to a specific bill. Additional sources of a more archival nature, held by the Library of Michigan ("Library") or the offices of the Michigan Legislature, include committee hearing transcripts, recordings of House and Senate debates, and videotapes of floor debates. These materials are primarily accessed by patronizing the Library or Legislature themselves, although some of this information is starting to make its way to the web. For example, some House Committees have begun to put committee hearing testimony, minutes, and other documents on their websites. ${ }^{68}$

\section{Other Sources}

- Lynn Hellebust, Michigan, in State Legislative Sourcebook 2008: A Resource Guide to Legislative Information in the Fifty States 197 (2008).

- 22 Mich. Civ. Jur. Statutes $\S 1-312$ (Thomson/West 2005 \& Supp. 2008).

- Michigan Department of History, Arts \& Libraries, Sources of Michigan Legislative History (2008), http://www.michigan.gov/hal/0,1607,7-160-17449_18639_18656-52439-,00.html (last visited Nov. 18, 2008).

\footnotetext{
${ }^{67}$ For more information on the sources discussed in this section see University of Michigan Law Library, Sources of Legislative History for Michigan (2006), http://www.law.umich.edu/library/students/research/Documents/Sources\%20of\%20Legislative\%20History\%20MI. pdf (last visited Nov. 19, 2008) or Michigan Department of History, Arts \& Libraries, Sources of Michigan Legislative History (2008), http://www.michigan.gov/hal/0,1607,7-160-17449_18639_18656-52439--,00.html (last visited Nov. 18, 2008).

${ }^{68}$ Linked from http://house.michigan.gov/committees.asp (last visited Nov. 13, 2008).
} 
- 29 Mich. L. \& Prac. Encyc. Statutes $§ 1-145$ (Mathew Bender \& Co. 2003 \& Supp. 2008).

- Michigan Legislature, How a Bill Becomes a Law, http://www.legislature.mi.gov/documents/Publications/HowBillBecomesLaw.pdf (last visited Nov. 18, 2008).

- Michigan Legislature, The Legislative Process in Michigan: A Student's Guide (2007), http://www.legislature.mi.gov/documents/Publications/StudentGuide.pdf (last visited Nov. 18, 2008).

- University of Michigan law Library, Sources of Legislative History for Michigan (2006), http://www.law.umich.edu/library/students/research/Documents/Sources\%20of\%20Legislative \%20History\%20MI.pdf (last visited Nov. 19, 2008)

V. Contact Information

Library of Michigan

702 W. Kalamazoo St.

P.O. Box 30007

Lansing, MI 48909-7507

Phone: $517-373-1580$

Fax: 517-313-4480

E-mail: librarian@michigan.gov

Website: http://www.michigan.gov/hal/0,1607,7-160-17445_19270---,00.html

State Law Library

Library of Michigan

Michigan Historical Center, Third Floor

702 W. Kalamazoo St.

P. O. Box 30007

Lansing, MI 48909-7507

Phone: $517-373-0630$

Fax: 517-373-3915

E-mail: Imlawlib@michigan.gov

Website: http://www.michigan.gov/hal/0,1607,7-160-17449_18639---,00.html 
Archives of Michigan

Michigan Library and Historical Center

702 W. Kalamazoo Street

Lansing, MI 48913

Phone: 517-373-1408

E-mail: archives@michigan.gov

Website: http://www.michigan.gov/hal/0,1607,7-160-17445_19273_19313---,00.html

Michigan Senate

P.O. Box 30036

Lansing, MI 48909-7536

Phone: 517-373-2400 (Secretary of the Senate)

Website: http://senate.michigan.gov/ and http://www.legislature.mi.gov/

Michigan House of Representatives

P.O. Box 30014

Lansing, MI 48909-7514

Phone: 517-373-0135 (Clerk of the House)

Website: http://house.mi.gov/ and http://www.legislature.mi.gov/

VI. Legislative Research Services

The Legislative Service Bureau is a non-partisan agency providing Michigan Legislature members with a variety of services including research. 